Stefan Kiedroń (Wrocław)

\title{
Jan Makowski (1588-1644). Polish Theologian in Frisian Franeker
}

When the first unambiguously Protestant - or, more precisely, Calvinist - university was opened in 1575 in Dutch Leiden (The Netherlands), only a few people could have assumed that it would soon attract young students from almost the whole of Europe who would come to The Netherlands to hear lectures given by world-famous Leiden scholars.

Theology faculties both in Leided and at the university in Franeker, established ten years later in distant Friesland, were to comprise the Calvinist 'ideological frame' of the academies. Characteristically, it was precisely at this faculty, which was supposed to create the stability so necessary for the Northern Netherlands at the time of the war waged against Spain, that incessant dogmatic disputes often assumed the form of personal quarrels brimming with charges (more or less justified) and leading to numerous divisions into the supporters or opponents of a given option. A famous controversy in Leiden involved the Arminians and the Gomarists (from the names of the leaders of the two camps), and an equally famous theological dispute took place in Franeker, where its vehemence and complexity made it necessary to turn for a solution to theologians debating in 1618-19 at the National Synod of Dordrecht, widely known not only in The Netherlands.

One of the dramatis personae was the Pole Jan Makowski, who enjoyed a brilliant career at the university in Franeker. Up to this day Calvinist theologians and historians of the Reformed Church in The Netherlands regard him as one of the outstanding theoreticians of Calvinist thought 
in that country. It is worth, therefore, to recall him and bring him closer to the reader.

Jan Makowski, known also under the Latinised version of his name as Johannes Maccovius, was born in 1588 in Łobżenica (Greater Poland) in the Calvinist family of Samuel Makowski. ${ }^{1}$ In 1604, at the age of 16, he was sent to Gdańsk, where at the local gymnasium he studied Latin and philosophy under the renowned Bartholomaeus Keckermann. Undoubtedly already in Gdańsk Makowski began developing the skill of conducting learned polemics and disputes with his religious opponents. The word 'polemics' seems to be the most suitable considering that subsequent events confirmed that Makowski's personality was definitely 'polemical'.

After completing his studies in Gdańsk Makowski set off to Prague (according to his biographer, Abraham Kuyper Jr.), where upon arrival he embarked upon a public polemic with the Jesuits. ${ }^{2}$ Subsequently, we encounter him in Lublin, where he was involved in a theological dispute with the Socinians, that is, the Polish Brethren. Next, Makowski left for a so-called peregrinatio academica; at the time, such extensive - frequently years-long - journeys to academic centres across the whole of Europe were made by all who wished to achieve 'worldliness' and could afford them.

On 13 September 1610 Makowski was enrolled at the university of Marburg together with three other Poles, representatives of the Calvinist circles of Little Poland. ${ }^{3}$ Marburg University was a Calvinist academy since 1605, a fact of great significance for the young Pole. On his way, he paid visits at the universities of Leipzig, Wittenberg and Jena, but since they were Lutheran he did not stay long or, even more so, did not enrol there.

After spending several months in Marburg, Makowski travelled to Heidelberg - the most prominent Calvinist centre in Germany. His name was recorded in the university book on 22 May 1611 as ephorus (that is, tutor) of the same three Poles with whom he had stayed in Marburg. ${ }^{4}$

1 Biographic data concerning Makowski in Polish in J. Tazbir, 'Makowski (Maccovius) Jan', in Polski Stownik Biograficzny, vol. 19/2, Wrocław, 1974, pp. 240-41, and in Dutch in A. Kuyper Jr., Johannes Maccovius, Leiden, 1899.

2 Cf. Kuyper, op. cit., p. 6.

3 They were: Marek Chyczki, Seweryn Boner, and Jan Seceminides; cf. Catalogus Studiosorum Scholae Marpurgensis, Pars quarta, ed. by J. Caesar, Marburg, 1875 (Kraus Reprint, Nendeln/Liechtenstein, 1980), p. 51.

4 Cf. Die Matrikel der Universität Heidelberg von 1386 bis 1662, ed. by G. Toepke, part 2: 1554-1662, Heidelberg, 1886 (Kraus Reprint, Nendeln/Lichtenstein, 1976), p. 254. 
Here too, Makowski developed his ars polemica, this time by conducting a dispute with the Jesuits from the close-by Spires. The outcome of this confrontation remains unknown but Johannes Cocceius (1603-69), author of a funeral speech given for Makowski, summed up the whole period of studies in glowing terms: 'Qua in peregrinatione magnum cumulum eruditionis collegit, plurimisque exercitiis atque colloquiis animum acuit, doctrinam solidavit'. ${ }^{5}$

If this had been the end of the scholarly career of the student from Greater Poland, he would have been ignored by later historians and probably remained only one of many verbi ministri, as Calvinist preachers were described. After a two-year long sojourn in Heidelberg, Makowski continued travelling, this time northwards, to the Republic of the United Provinces, that is, the Northern Netherlands. He did not, however, choose as the new place of studies the university of Leiden, where many Polish students were already staying. This decision was probably affected by the fact that the Poles, whom he accompanied, this time as their tutor, resolved to study here.

On 24 October 1613 the following students were listed in the book of the university of Franeker:

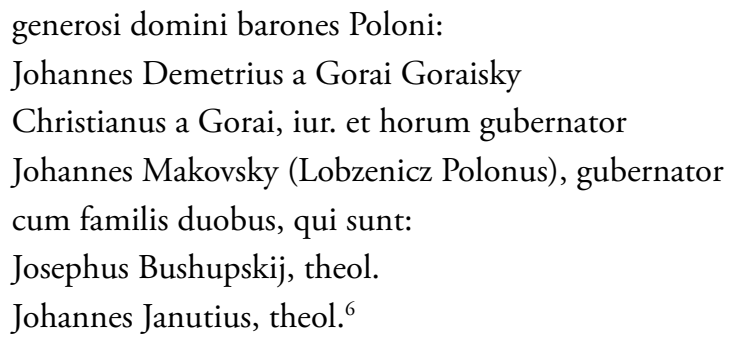

The mentioned 'barones Poloni' were also Calvinists from Little Poland.' Their ancestor, Adam Gorajski, was the founder (in 1578) of the town of Biłgoraj and the local Calvinist church; the Gorajski family was also the owner of Jedlińsk near Radomsko, the site of a renowned school at the local Calvinist church, another foundation of Adam Gorajski. Other

5 Kuyper, op. cit., p. 6.

6 Album Studiosorum Academiae Franekerensis (1585-1811, 1816-1844), I. Naamlijst der Studenten, ed. by A. Fockema S.J., Th. J. Meijer, Franeker, [1968], p. 53.

7 Cf. S. Tworek, Dziatalność oświatowo-kulturalna kalwinizmu matopolskiego (potowa XVI $w$. - połowa XVIII w.), Lublin, 1970, pp. 144, 183, 289. 
members of the Gorajski family fulfilled high state functions; by way of example, Zbigniew Gorajski (who, nota bene, studied in Leiden since 1616) was the castellan of Chełm and Kiev. Demetrius Gorajski, the first mentioned Polish student, presented samples of his talent as a poet when in 1612 he wrote epigrams to a work by another Calvinist from Little Poland, Salomon Neugebauer. ${ }^{8}$ One of the mentioned 'famili', Józef Biskupski (who soon, in 1641, was to conduct a public dispute under Makowski's supervision: De iustificatione hominis peccatoris coram Deo) became, after completing his theological studies abroad, rector of a well-known Calvinist gymnasium in Bełżyce. ${ }^{9}$ Fate would have it that one of his predecessors holding this post was Makowski's brother, Maciej. Other brothers of the future famous scholar of Franeker also held honourable posts: Jakub became a receiver in Torun, and Samuel - a physician; both traversed an academic path similar to the one followed by Jan by studying first in Marburg and then in Groningen and Franeker.

While on the subject of family connections, it is worth drawing attention to Jan Makowski's indirect affiliation with Rembrandt via his wife, Antje Uylenburch, sister of Saskia, wife of the famous painter. ${ }^{10}$

In this company the young Makowski arrived in Franeker. True, the Gorajskis were the first Polish students at this university but by no means the last thanks to their tutor.

While studying at the theological faculty, Makowski wrote his doctoral dissertation, which he presented soon afterwards, in the following year.

Meanwhile, let take a closer look at the situation prevailing at the faculty at the time of Makowski's arrival.

In 1585, the year of the establishment of the University of Franeker witnessed the introduction of three posts for professors of theology. The appointments were made rapidly, and during the first thirty years of the academy's existence the situation was quite calm in contrast to Leiden torn by incessant theological disputes: here, 15 professors changed in the course of the first 25 years. ${ }^{11}$ This unruffled state of things was the accomplishment predominantly of Martinus Lydius (1539-1601), profesor primarius,

$\begin{array}{ll}8 & \text { Ibid., p. } 261 . \\ 9 & \text { Ibid., p. } 217 .\end{array}$

10 Cf. Z. Batowski, 'Rembrandtowskie otoczenie i Polacy', in Ksiega pamiątkowa ku czci Leona Pinińskiego, vol. 1, Lviv, 1936, p. 7.

11 Cf. W. Otterspeer, Werkplaatsen van Wijsheid, Geleerdheid en her Warc Geloof of de Wisselwerking tussen de Universiteiten van Leiden en Franeker, Franeker, 1985, p. 46. 
tirelessly pacifying emergent conflicts. The stance of another professor, Henrikus Antonides Nerdenus (actually: Van der Linden, 1546-1614), also contributed to the unperturbed atmosphere prevailing at the faculty. On the other hand, the third professor, Sibrandus Lubbertus (1555-1625) was, according to his contemporaries, quarrelsome, intolerant and obstinate. His whole life was full of conflicts and controversies, the first being a polemic against distant opponents. Lubbertus first attacked the pope and the Jesuits, then the Socinians, and subsequently the Arminians, already closer to his camp but representing a different view of Calvinist theology than the one he propounded. Finally, Lubbertus chose as his opponent a colleague from the same university, the celebrated Hebraist Johannes Drusius (1550-1616). He remained alone at the theological faculty after the death of Lydius and then Nerdenus. The year was 1614, and Makowski was preparing his theological doctoral thesis.

In this manner the two great opponents of the future dispute met. We know that Lubbertus willingly took part in the debates and that Makowski was fond of polemics. In other words, both men had similar personalities. The biographers of the theologians, however, assessed them quite differently. A. Kuyper Jr., author of Makowski's biography from $1899,{ }^{12}$ decidedly took his side and ascribed all the bad traits to Lubbertus. In turn, more than sixty years later, C. van der Woude in his biography of Lubbertus $(1963)^{13}$ tried to adjust the extremely negative portrait of the professor. It seems, however, that neither author offered convincing arguments in favour of his theses. Let us, therefore, adhere to the statement about similar personalities. Naturally, the two opponents' age and position varied. Makowski was a debuting theologian, barely 26 years old, an experienced participant of polemics with his adversaries and despite the fact that he was only a student, unquestionably extremely ambitious. Lubbertus - also hardened in theological disputes - was already 59 years old and the sole professor at the most important faculty at Franeker University. He expected, therefore, to be respected and recognised.

On the other hand, one should avoid superficial assessments. The emergent conflict was certainly not caused exclusively by temperament or difference of age. Such reasons were accompanied by more profound

12 Kuyper, op. cit.

13 C. van der Woude, Sibrandus Lubbertus. Leven en werk, in het bizjonder naar zijn correspondentie, Kampen, 1963. 
roots in the attitude of both theologians to the teachings of the Reformed Church, in particular to the fundamental problem of predestination.

From the early seventeenth century a different interpretation of this question was the source of a dispute generating a religious rent throughout the whole Republic of United Provinces. I have in mind the above-mentioned controversy involving Jacobus Arminius (1560-1609) and Franciscus Gomarus (1563-1641), professors of theology at Leiden. Arminius and his adherents (later known also as the Remonstrants) attached a great role to man's freedom of decision regarding his faith in God. On the other hand, Gomarus and his supporters (the Counter-Remonstrants) were of the opinion that God alone decides who is chosen and who is condemned. The Counter-Remonstrants comprised a majority in the Reformed Church, but for some time (even after the death of Arminius) the impact exerted by the Remonstrants remained discernible. Meanwhile, the question of predestination caused a split among the Counter-Remonstrants into two camps: the infralapsarists and the supralapsarists. Makowski regarded himself a member of the supralapsarist camp, and Lubbertus - of the infralapsarist one.

The supralapsarists maintained that God divided people into the chosen and the condemned already prior to the fall of Adam (ante lapsu), while the infralapsarists were convinced about an opposite sequence of the history of the world. First, there took place the sin of the fall and only then (post lapsum) did God decide to redeem those people who acted in accordance with His commandments; all others were condemned. ${ }^{14}$

Both visions contain elements that, developed to the limits of consequence, could prove to be dangerous for the doctrine. If the supralapsarists were right, then there arises the question whether man has any sort of chance for salvation unless he belongs to those chosen by God. If, however, it is the infralapsarists who are correct then one could ponder whether God's omnipotence began after the fall of Adam Makowski's supralapsarism assumed form already in Gdańsk, while he studied under Keckermann. The infralapsarism embraced by Lubbertus had been firmly grounded many years prior to Makowski's arrival in Franeker. The stand represented by Lubbertus can be deciphered in the titles of the works written under his guidance by students of theology. One of these studies,

14 K. Dijk, De Strijd Infra-en Supralapsarisme in de Gereformeerde Kerk in Nederland, Kampen, 1912, passim. 
completed in 1613, that is, the year of Makowski's arrival, was entitled: Disputatio theologica de miseria hominis post lapsum. ${ }^{15}$

Initially, however, nothing indicated the possibility of a dispute and even more so of personal animosity. Lubbertus was the promoter of Makowski's dissertation under the rather general title: De Ecclesia, submitted with success on 8 March 1614. True, Lubbertus acted as the promoter as if ex officio - he was the sole professor at the faculty - but he assessed Makowski's work very highly: 'cum luculentissimo testimonio'. ${ }^{16}$ Quite possibly, Lubbertus' thoughtfulness was enhanced by the memory of his contacts with Makowski's teacher from Gdańsk. Keckermann regarded Lubbertus to be one of the 'rari aevi hujus Theologi' - an exceptional theologian of the century; this opinion was expressed in a letter from 1608 in which he thanked Lubbertus for his persistence in combating 'Socinian heresies'. ${ }^{17}$ Yet another factor could have influenced the attitude represented by Lubbertus vis à vis Makowski: the young doctor 'Sacrosanctae Theologiae' did not as yet pose a threat.

This argument became more distinct once we observe Lubbertus's further activity involving Makowski. Having won the title of doctor, the Pole could commence lecturing - he rapidly embarked upon this task and attracted numerous students. Lubbertus praised him highly and recommended for the post of professor of theology at the university of Groningen. This academy - the third in the Northern Netherlands, was in the throes of being organised. Just as in Leiden and Franeker here too the most prominent was the theology faculty. The honour, therefore, was great and Makowski's willingness even greater. Unfortunately, these plans came to nought - Makowski did not receive the nomination and stayed on in Franeker where as 'private dozent' he gave lectures, which he called 'Systema breve Theologiae' ${ }^{18}$ and which enjoyed increasing popularity among the students.

It was precisely the students who at a certain moment - when it was already common knowledge that Makowski would not become a professor at Groningen - filed a petition to the university curators who, in

15 Disputationes execritii gratia, een inventarisatie van disputaties verdedigd on der Sibrandus Lubbertus, Prof. Theol. te Franeker 1585-1625, ed. by F. Postma, Amsterdam, 1985, p. 71.

16 Kuyper, op. cit., p. 11.

17 Woude, op. cit., p. 135.

18 Kuyper, op. cit., p. 20. 
turn presented it (on 22 November 1614) to the Frisian Estates. The petition maintained:

\begin{abstract}
The Academy in Franeker has only a single professor of theology instead of three, as is fitting, and Johannes Maccovius could be employed for a small fee. The same Maccovius is a person of merit and excellent learning, also experienced in theology and assorted sciences, extremely agreeable to the students, and without doubt would add spendour to the Academy in Franeker and attract students from all over, as could be already seen; therefore, might the Lords [Curators] for those and other reasons recognise that this Maccovius as Profesor extraordinarius in the Holy Writ [...] be employed and lecture on locos communes and pertinent themes $[\ldots] .{ }^{19}$
\end{abstract}

The petition was accepted and considered by the Frisian Estates, which in the meantime made efforts, albeit never realized, to engage two other theologians. In the case of Makowski the decision was rapid and, more important, positive. On 28 January 1615 Makowski was elected by a majority of votes professor extraordinary of the theological faculty, with an annual wage of 500 guldens.

Presumably, this majority of votes did not include the vote of Lubbertus since soon after the fiasco of efforts to win a professorship for Makowski in Groningen rumour had it that Lubbertus opposed him. If these speculations were true - and this is not entirely certain - they would have been a sign that Lubbertus started treating Makowski as a threat for his position already after the doctoral promotion. Characterstically, Lubbertus wholeheartedly recommended Makowski in Groningen but refused to do so in Franeker.

On the other hand, it is difficult to imagine that a nomination to such an important post would have been made without talking it over with the sole professor of the faculty. A discussion, however, does not denote consent. Nothing is known about the details of the conducted negotiations with the exception of the ultimate, affirmative, decision.

Meanwhile, the further course of events increasingly exacerbated relations between the two professors.

19 F. Postma, J. Veenhof, 'Disputen omtrent de predestinatie. Het logisch denken van Johannes Maccovius (1588-1644) en de doorwerking daarvan', in Universität te Franeker 1585-1811. Bijdragen tot de geschiedenis van de Frise hogeschool, ed. by G. Th. Jensma, F.R.H. Smit, F. Westra, Leeuwarden, 1985, pp. 249-63, here p. 249. 
Several months after his nomination Makowski received a higher post: on 16 June 1615 he was appointed professor ordinary lecturing on 'loci communes Theologiae' and 'Physicae Doctrina'. His wages were raised to that of the other professors, that is, 600 guldens per annum. In other words, Makowski now enjoyed a rank equal to that of the remaining professors at the Franeker academy, including Lubbertus. Despite his young age (he was only 27 years old) he had ascended almost all the possible rungs of a university career with the exception of the uppermost, which he was to achieve rapidly when in November of the same year the heretofore rector, Augustinus Lollius Adama, professor of medicine, was dismissed. Nota bene, at the time, the office of the rector was organised differently than is the case today. The term of office lasted for only a year - from 1 June to 31 May of the following year. In other words, Adama had not fulfilled his function for long, and on 1 December a system of monthly 'replacements' was established to the end of the term of office. The first to perform the duties of the rector was Jan Makowski (December 1615). True, he did not have the official title of rector (university records mention: 'Praeside Johanne Makovsky sanctissimae theologiae professore ordinario'), ${ }^{20}$ but for this brief time he remained the highest authority at the academy.

Soon after Makowski was officially elected rector for a term of office spanning from 1 June 1617 to 31 May 1618.

The career of the young Pole was, therefore, extraordinary and rapid - from student in 1613 to rector in 1617. For his next term of office, however, Makowski had to wait 15 years, that is, until 1633.

Lubbertus too held the post of rector twice: in 1589-90, and then in 1624. The interval, therefore, was almost 25 years long, and he did not complete the term of office since the university books recorded: 'dominus Lubbertus obiit in rectoratu X januarii [1625]'. ${ }^{21}$

Meanhwile, relations between Makowski and Lubbertus became outright hostile. The first conflicts involved petty issues - the time of lectures: Makowski chose 8 a.m., which coincided with the lecture given by Lubbertus. This was undoubtedly a sign of rivalry for prominence at the faculty. Lubbertus regarded it as an obvious insult but was unable to alter the situation. In the meantime, Makowski (whom Lubbertus

20 Album Studiosorum Academiae Franekerensis..., op. cit., p. 57.

21 Ibid., p. 76. 
described as a 'Sarmatian') began publicly attacking other professors. At his lectures, which continued to be popular among the students, he described his colleagues as insufficiently educated and accused his promoter of knowing little about theology apart from the most basic things, adding that it was a pity that 'talented and educated young men' ('ingeniosos et eruditos juvenes' ${ }^{22}$ ) wasted time listening to his lectures.

In other words, Makowski had an extremely high opinion of himself and evidently wished to win the approval of the students. He still regarded himself as a student and took part in frequent social events, often giving rise to public scandal, and even fought in duels (which were forbidden).

Lubbertus, on the other hand, supported strict discipline and intended to introduce it among the unruly students. It is not surprising that the latter opted for Makowski. Lubbertus also aimed at restricting the influence exerted by Makowski as much as possible and, as a consequence, at ejecting him from the academy.

First steps made by Lubbertus took place already in 1616, when the Hebraist Drusius, with whom he was engaged in a fierce dispute, died on 12 February. Makowski gave the funeral speech in the presence of the entire university community.

As was the custom, the speech was to be published. This never took place as a result of Lubbertus' efforts behind the scene, probably caused by the still strong hostility towards the deceased and growing inimity towards Makowski and his activity.

Since, as has been said, reasons for the ensuing vehement conflict were deeper (that is, stemmed from a different approach to basic theological questions, and in particular predestination), Lubbertus started seeking all possible ways to resolve the controversy in a manner favourable for him upon the theological level. Instead, however, by aiming at a swift end to the dispute - this undoubtedly must have been his intention - he changed a local debate into an almost international one.

The first attempt at discrediting his adversary was made by Lubbertus in 1616 in connection with a dissertation about predestination written under Makowski by the student Lambrecht Ernest Hidding.

Hidding maintained, for instance, that Christ did not want the salvation of all and sundry ('Christus non vult omnium et singulari salutem' ${ }^{23}$ ),

22 Woude, op. cit., p. 344.

23 Kuyper, op. cit., p. 24. 
that $\sin$ is necessary since without it man's subsequent misery would not come into being, and that without the latter God's mercy would not exist ('Sine peccato nulla futura erat miseria; sine miseria non erat futura misericordia ${ }^{24}$ ). These statements could produce the conclusion that God was the cause of sin and this was exactly the inference drawn from Hidding's 'rotunda verba' by Ubbo Emmius (1547-1625), the first rector and professor of theology in Groningen ('[...] Hiddingus [...] asseritur rotundis verbis Deum autorem et causam esse peccati' $\left.{ }^{25}\right)$. The Church authorities in Franeker (which wielded theological supervision also over the university) received a complaint against Makowski accused of inspiring such shocking opinions; Makowski suspected that it had been filed by Lubbertus. The motion, however, was not examined and Makowski could continue voicing his supralapsaristic views.

At the beginning of 1617 there appeared in Franeker the English student Thomas Parker who, under Makowski, wished to conduct a dispute about guiding sinners towards eternal life ('Thesae Theologicae de Traductione Hominis Peccatoris ad Vitam ${ }^{26}$ ). Originally, Parker wanted to present his theses at Leiden but none of the local professors was willing to conduct the controversial disputation. Consequently, it was held in Franeker where it produced Lubbertus' determined objection. The Church authorities once again received a complaint against Makowski (this time Lubbertus protested against the suggestion that he had been its author, albeit he undoubtedly inspired it). The critical charge contained fifty accusations based mainly on Parker's theses as well as on those formulated by Makowski. The theses in question were to be irrefutable proof that the Pole had embraced Lutheran, papist, Socinian, Pelagianist, and even - horrible dictu - pagan views. Makowski supposedly negated that God's mercy is eternal and was to have declared that God did not wish to redeem the whole of mankind and that man possesses the gift of life. ${ }^{27}$

Such a serious charge could not be ignored and a sentence was passed at the beginning of 1618: Makowski was pronounced guilty of heresy. The Pole, however, appealed to a higher instance - the Provincial Synod of Friesland, which that year was holding its session in Friesland. The

24 Ibid., p. 25.

25 Ibid., p. 24; Woude, op. cit., p. 345.

26 Kuyper, op. cit., p. 26; Woude, op. cit., p. 350.

27 All fifty theses in Latin in Kuyper, op. cit., p. VI ff., appendix C. 
Synod, however, refrained from making a decision and entrusted the case to a state instance: the Frisian Provincial Estates, which on 3 October 1618 set up a special commission to hold talks with both sides. When the negotiations failed to produce a result, the Provincial Estates decided (18 November 1618) to present the issue to a supreme Church instance: the National Synod, sitting in Dutch Dordrecht and attended by numerous Calvinist theologians from abroad.

Presumably, none of those successive instances was capable of making the ultimate decision. The reason for this state of things (undoubtedly referring also to the charge against Makowski formulated in 1616 and never considered) is to be found in the still unresolved controversy involving the Remonstrants and the Counter-Remonstrants. It was exactly in order to finally settle the question of the Remonstrants that the National Synod met. The dispute raging among the Counter-Remonstrants and involving the supralapsarists and the infralapsarists could have, in the opinion of the majority of the supporters of the Counter-Remonstrant Gomarus, been exploited by the Remonstrants.

Gomarus understandably played an extremely important part at the Dordrecht Synod. ${ }^{28}$ In view of the fact that he was a member of the supralapsarist camp, Makowski could have counted on a favourable outcome. On the other hand, a rejection of the arguments presented by the infralapsarists might have resulted in increasingly great divisions within the Counter-Remonstrants.

The errors Makowski was charged with were produced also by his overly consistent use of the scholastic method in teaching theology. The method in question, introducing elements of Aristotelian philosophy into Calvinist theology, was applied also by other theologians in the Northern Netherlands (including Lubbertus), but none had gone so far in proclaiming radical scholastic theses as Makowski.

In this extremely complicated situation, the National Synod in Dordrecht was to make a final decision regarding an issue described in the order of the day as: 'causa particularis Frisica'. ${ }^{29}$

The rank of the sides involved in the controversy was unequal. Lubbertus was officially delegated (3 November 1618) to the debates of

28 Cf. G. P. van Itterzon, Franciscus Gomarus, Groningen-Castrium, 1979, p. 185.

29 'Maccovius, door de Dordrechtse Synode ten jare 1619 besiecht', in Archief voor Kerkelijke Geschiedenis, inzonderheid van Nederland, Part 3, Leiden, 1831, pp. 503-664; abbreviated description in Kuyper, op. cit., p. $82 \mathrm{ff}$., and in Woude, op. cit., p. $357 \mathrm{ff}$. 
the Dordrecht Synod by the Provincial Estates of Friesland as the oldest professor of theology at the Franeker academy. The official opening of the Synod took place on 13 November 1618, but Lubbertus was absent since he had been attending the discussions still conducted in Franeker. Urged to appear in Dordrecht, he arrived on 23 November, greeted as a man of 'excellent wisdom, knowledge and experience'. ${ }^{30}$ At the time, the Estates decided to present the controversy to the Synod in Dordrecht. On 28 November Makowski received consent to leave for Dordrecht and 200 guldens (that is, one-third of his annual remuneration) to cover the costs of the journey and stay, and which he was obligated to return in case of a condemning sentence.

Upon arrival in the Dutch town Makowski was compelled to wait almost five months before the Synod undertook any sort of steps. The cause of the delay was simple: first, it was necessary to ultimately tackle the Remonstrants and only then to deal with disputes raging within the opposing camp. Impatient, Makowski dispatched a letter to the Synod requesting that after so many months of waiting his case should be examined and he instructed about his errors or cleared of all charges. $\mathrm{He}$ also presented the accusations, described the reasons for the controversy, and placed the whole blame on Lubbertus. More even, Makowski also asked that both sides should be heard by the whole Synod or a specially created commission, whose half would be chosen by him and the other half by Lubbertus.

Makowski could have feared that he would be not allowed to speak, thus sharing the fate of the Remonstrants, found guilty of heresy in absentia solely upon the basis of their writings. His letter, however, was read in the presence of the whole Synod at the $138^{\text {th }}$ session on 25 April 1619, that is, exactly a day after the resolution of the case of the Remonstrants. The gathered theologians also heard Lubbertus, who declared that he was not a side in the dispute but only played the role of spokesman of the Church authorities in Franeker. The Synod decided to first become acquainted with the official text of the accusations and the connected documents and only then to decide about eventually hearing Makowski.

The text of the charge, containing fifty points already known from the theses presented by Parker and Makowski, was thus read before noon on the following day, 26 April. Makowski's successive letter with another

30 Woude, op. cit., p. 357. 
request for hearing him personally was not read, since in the opinion of the chairman of the debates, Johannes Bogerman, it included personal accusations detrimental to the dignity of Lubbertus.

The majority of the gathered theologians asserted that the charges addressed against Makowski could be reduced to four or five, and that certainly not a single one was a 'crimen haereseos'.

In the afternoon of the same day (the $141^{\text {st }}$ session) two responses formulated by Makowski and rejecting the charges were read aloud. Makowski, however, was not allowed to present his arguments publicly before the whole Synod. On the other hand, a day later, on 27 April, having listened to the opinions of a number of theologians, including Gomarus - and the majority of those statements was rather conducive for the Pole - it was decided by a majority of votes to establish a six-person commission, which once again was to examine the whole case in detail and propose a solution to the Synod. The commission sat for several days to become acquainted with a third letter written by Makowski, claiming that his theses had been either wrongly interpreted or were confirmed by the Bible. This letter too, according to the commission, included insults aimed against Lubbertus. After a several days long discussion, the commission arrived at an opinion that Makowski upon occasions expressed himself unclearly and ambiguously but was not guilty of proclaiming heresies. The Synod thus recommended members of the commission to bring about conciliation between both sides. Once again, several days passed before the commission - having consulted Makowski and Lubbertus - arrived at a comprise formula, which it presented to the Synod for confirmation. The latter verified it by a majority of votes at the $152^{\text {nd }}$ session held on 4 May 1618. The final verdict composed of three points, was as follows:

1) Makowski's theses did not proclaim Socinian, Pelagianist or any other heresies;

2) Makowski was reprimanded that in the future he should avoid the use of formulations that could shock young people; he should also select topics of disputations that would reaffirm young people in the orthodox doctrine; furthermore, he should shun in particular opinions that expressed without a suitable commentary could annoy 'simpletons' ('simpliciores'); ${ }^{31}$ in addition, he should take care to keep peace with his

31 Kuyper, op. cit., p. 94. 
university colleagues and urge young students to demonstrate respect for their teachers;

3) those who accused Makowski should refrain from such charges in the future if they do not possess serious proof ('graviora documenta'). ${ }^{32}$

Both adversaries accepted this decision and synodal documents recorded: 'Amice transacta fuit causa Frisica'. ${ }^{33}$

Nonetheless, the controversy did not end in conciliation. On the contrary: already the next year, 1620, the university senate summoned Makowski (on 29 November) demanding that he present explanations concerning several theological questions about which his opinions were decidedly at odds with those of Lubbertus. They included, for instance, the question whether Christ was resurrected 'propria virtute ${ }^{34}$ - as Makowski claimed - or thanks to the will of God, as Lubbertus maintained. Another controversial issue was a distinction of the concepts of 'sufficiencis' and 'efficacia' in reference to the redemption of sins by Christ's death on the Cross. Lubbertus declared that the death of Christ was 'sufficient' for the redemption of the original sin of all people but effective ('efficax') only in the case of those chosen by God. Makowski was of the opinion that such a distinction was foolish ('distinctio vanissima'). ${ }^{35}$

This dispute too had its roots in a controversy involving the infra- and the supralapsarists and as previously it did not end in a decisive solution. Initially, Makowski did not respond to the summons issued by the senate, and only after being admonished did he dispatch one of his students to act in his name. The whole case was presented to the Provincial Estates, which on 26 January 1621 set up a commission to ultimately resolve the conflict. The final verdict was an almost literal repetition of the solution from Dordrecht.

At the same time, it should be stressed that the distinction between the concepts of 'sufficiencis' and 'efficacia' produced considerable objections also among friends and adherents of Lubbertus. Soon, however, Lubbertus was to gain support in his conflict with Makowski. The first to unambiguously stand by his side was Sixtinus Amama (1593-1629), professor of Hebrew in Franeker. Initially, Lubbertus was a determined adversary of this student and then (since 1616) successor of Drusius.

32 Ibid., p. 95.

33 Woude, op. cit., p. 362.

34 Ibid., p. 365.

35 Ibid., p. 367. 
In time, however, their relations improved and when in 1621 Amama was elected rector, he decided together with Lubbertus to embark upon activity intent on putting an end to students' excesses. Amama considered Makowski to be the spiritual (and sometimes physical) leader of the students. Younger by five years (Amama became professor at the age of 23), he claimed that the Pole had a bad influence upon the students.

New professors appointed in the following year (1622) included the Englishman William Ames (Guilielmus Amesius; 1576-1633), who received the vacant office of the third professor of theology (for a short time, in 1617-1618, this post was occupied by Johannes Acronius, who latter fulfilled the function of a preacher in assorted Calvinist congregations), and Johannes Hachting (1594-1630) who became professor of logic and was only slightly older than Makowski when the latter was appointed professor.

Both Amesius and Hachting stood by Amama and Lubbertus, aware of the need for a profound reform of university life and disciplining the students.

Rumours even claimed that Makowski was to be temporarily suspended as professor of theology. ${ }^{36}$ University records, however, do not contain any pertinent mentions. It is known, nonetheless, that alongside theological lectures Makowski also organized private courses on logic, this intruding into Hachting's domain. The latter turned to university curators with a request to stop this practice, but to no avail. Next, Hachting announced a public disputation on the thesis: 'Praecepta logica [...] debent esse in omnis brevia, vera, utilia, concinna', ${ }^{37}$ thus making it obvious that the lectures on logic conducted by Makowski were neither concise, true, and useful nor well constructed. Although the rector forbade the disputation, he did not prevent a new conflict.

In other words, Makowski did not win over adherents while Lubbertus could rely on the support of new colleagues. The relations between him and the Pole did not improve. For a short while it seemed that Makowski would leave for Poland but this did not take place. Lubbertus mentioned in one of his letters: 'The Sarmatian is leaving for Poland but asks for

36 Cf. ibid., p. 364.

37 K. van Berkel, 'Franeker als centrum van ramisme', in Universität te Franeker..., op. cit., pp. 424-37, here p. 427. 
a raise in wages. From this I deduce that he is not thinking about staying in Sarmatia'. ${ }^{38}$

An end to the dispute between the two adversaries was put by the death of Lubbertus in January 1625. The funeral speech was given by Amama, who avoided any mention of his former conflicts with Lubbertus and enumerated the latter's assets and contributions to the Church and the Franeker academy. Lubbertus was succeeded by Meinardus Schotanus (1593-1644), recommended by Amama.

When in the following year (1626) Armesius was elected rector, he commenced the realization of his 'reform programme' focused on the university. This was a decidedly Puritan programme - in 1610 Amesius translated William Bradshaw's English Puritanisme into Latin (Puritanismus Anglicanus); in a preface he presented a portrait of the good Christian, ${ }^{39}$ which he now decided to implement. This activity was first and foremost aimed against Makowski. Together with Amama, Hachting and Arnoldus Verhcl, a professor of philosophy, on 2 June 1626, that is, soon after being elected rector, he dispatched a document to the university curators containing extremely grave accusations against Makowski. In the introduction, the authors of the letter referred to the controversy from 1620, declaring that if the curators had been more consistent at the time as regards Makowski and his erroneous stand, then the current (that is, in 1626) situation would have never taken place. A list of charges followed: Makowski caused outrage ("What shall we say to the Jesuits, the Anabaptists and Socinians when such a person harms You, us and our whole Church?'); ${ }^{40}$ even after the death of Lubbertus, Makowski derided him; Makowski got drunk; Makowski fought a duel; Makowski derogated the good name of his colleagues-professors and deprived them of their students, setting a bad example. ${ }^{41}$ The consequences of the letter signed by the four professors remain unknown. The accusations were extremely grave but did not result in discharging Makowski from the academy. Nevertheless, the relations between him and other professors were tense and he was not admitted to senate sessions. This state of things went on for several years, until finally, in May 1629, the Provincial Estates,

38 Woude, op. cit., p. 367.

39 Universität te Franeker..., op. cit., pp. 264-74, here p. 268.

40 Kuyper, op. cit., p. 44.

41 Ibid. 
having ascertained an improvement of Makowski's behaviour, allowed him to participate in the senate sessions. ${ }^{42}$

Soon, two of his adversaries passed away: Amama died in November 1629 and Hatching in September 1630. Their deaths marked the end of significant controversies involving the local professors. On the one hand, Makowski was now the longest working professor at the most important faculty while, on the other hand, he was no longer the bellicose theologian who elevated himself while humiliating others. With time, his temper grew milder and his authority among colleagues increased to such a degree that Schotanus, a former protégé of Amama, proposed Makowski for professor of logic, a post once held by Amama; only a few years earlier this had been a bone of contention among the professors.

The prevailing mood was finally soothed by Makowski's election for rector in May 1633. In the same year William Ames left Franeker for Amsterdam, well aware of the fact that his 'Puritan reformation of the university' had ended in a fiasco.

From that moment, all controversies concerning Makowski ceased. He was without doubt a contentious figure and the dispute he conducted with Lubbertus produced a considerable rift among Calvinist theologians in the Netherlands. Echoes of that controversy resounded centuries after the events described above. In his biography, Abraham Kuyper Jr. depicted not only Makowski but also the ideas propounded by the group headed by his father, Abraham Kuyper Sr., a renowned theologian (founder of the Calvinist Free University of Amsterdam) and politician (founder of the Anti-Revolutionary Party and prime minister in 1901-1905). Briefly, these ideas reflected the supralapsarist theses revived in as late as the nineteenth and twentieth centuries (take the example of Geen Christus pro omnibus [Christ was not for all] by Kuyper Sr., from 1884). In 1905 the study by Kuyper Jr. on Makowski, presented as a doctoral dissertation at the Free University of Amsterdam, produced numerous protests, and Kuyper's activity and that of his students resulted in the convention of a synod in Utrecht, entrusted with resolving the controversy. This was a repetition of the Dordrecht convention. The Synod resolution was also similar: Kuyper Jr. was not condemned but was obligated to express his

42 Cf. W. B. S. Boeles, Frieslands Hoogeschool en het Rijks-Athenaeum te Franeker, Part 1, Leeuwarden, 1878, p. 49. 
views in a better-thought-out manner. The dispute remained unresolved and ultimately, in 1944, it resulted in a schism. ${ }^{43}$

One could say that Makowski's impact was discernible indirectly 300 years after his death in 24 June 1644. Naturally, his direct influence was greater during his lifetime, to mention only its effect upon his compatriots. At the beginning of this sketch mention was made of the fact that Makowski and the brothers Gorajski were the first Poles in Franeker. Already in the following years, however, numerous other Poles arrived, attracted by the renown of the young professor. Up to 1644 more than 80 Poles studied at the Franeker academy, of whom half at the theology faculty. They included such known persons as Andrzej Węgierski (from 1628), Andrzej Morstin (from 1637), Jan Szydłowski (from 1640) and Mikołaj Arnoldi (1618-80) aka Nicolas Arnoldus (from 1641).

The latter is particularly prominent in the context of Makowski's activity in Franeker since Arnoldus, Makowski's student, continued his work. When in 1650 Johannes Coccejus, from 1636 professor of Hebrew in Franeker, and from December 1643 professor of theology (he did not receive his doctoral degree until February 1644!), ${ }^{44}$ left for Leiden, his post was entrusted in 1651 to Arnoldus.

Arnoldus was known as an extremely orthodox and conservative theologian, combating particularly vehemently all Cartesian theses and claiming that the Bible cannot be interpreted with the help of sciences other than theology. ${ }^{45}$ His authority was so considerable that he was elected rector upon four occasions (in 1653, 1661, 1671, and 1676). Arnoldus was also known as the publisher of Makowski's works; Makowski issued only some of his writings during his lifetime. The collection: Miscellanorum Questionum Publice Disputatarum in Academia Franekerana, published in 1632, contained texts of public disputations conducted under his supervision in 1618-32. The year 1639 witnessed the second edition of Volumen Thesium Theologicarum per Locos Communes, and 1641: the third edition of Collegia Theologica, quae extant omnia, dedicated to Prince Radziwiłł. Soon after Makowski’s death Arnoldus began preparing a full edition of his teacher's works. Maccovius Redivivus, containing,

43 Cf. Postma, Veenhof, op. cit., p. $259 \mathrm{ff}$.

44 A. P. van Nienes et al., De archieven van de Universität van Franeker 1585-1812, Leeuwarden, 1985 , p. 89.

45 Biographisch Woordenboek van protestantische Godgeleerden in Nederland, ed. by J. P. de Bie, J. Loosjes, Part 1, 's-Gravenhage, [no date], p. 254. 
for instance, Theologia Polemica, Casus Conscientia, and Anti-Socinus, appeared in Franeker already in 1647. In 1654 Arnoldus issued a second edition of Makowski's collected works expanded, for instance, due to the inclusion of Fragmenta Praelectionum contra Arminium, Theologia Quaestionum, Fragmenta Praelectionum contra Catechesin Socini, and Distinctiones Theologicae. The latter text was translated into the Dutch: De Gods-geleerd Onderscheydingen, and published in Amsterdam in 1658.

Meanwhile, Arnoldus also issued Makowski's chief work: Loci Communes; the first edition appeared in Franeker in 1650 and the second - in Amsterdam in 1658. Finally, Makowski’s last work published by Arnoldus: Opuscula Philosophica Omnia, was printed in 1660. It was composed of, for instance, De Usu Logicae Lib. III, Breve Systema Rhetoricae, Systematis Physici Lib. III, Metaphysica Theoretica-Practica, Tractatus Philosophiae Practicae, Ethici, Politici, Oeconomici, and Modus Legendarum Historiarum. ${ }^{46}$

This long list of writings by Makowski ${ }^{47}$ demonstrates clearly the extent of his interests. Nonetheless, Makowski remains acclaimed predominantly as the most consistent supralapsarist ${ }^{48}$ - the most famous Polish theologian in the Northern Netherlands.

\section{Translated by Aleksandra Rodzinska-Chojnowska}

First published as: 'Jan Makowski (1588-1644). Polski teolog we fryzyjskim Franekerze', Odrodzenie i Reformacja w Polsce, 40, 1996, pp. 37-51.

46 Cf. Kuyper, op. cit., p. III ff., appendix B.

47 Makowski's witings were featured at an exhibition held in 1978 in Gdańsk (and other Polish towns); cf. L. Thijssen, R. de Leeuw, Związki między Holandia i Polska wXVII w., [exhibition catalogue], Gdańsk, Słupsk, Kielce, and Warsaw, 1978, p. 90 ff. 48 R. Seeberg, Lehrbuch der Dogmengeschichte, vol. 4/2, Erlangen and Leipzig, 1920, p. 685 . 